\title{
Factors Influencing Macrophyte Species Richness in Unmodified and Altered Watercourses
}

\author{
Justyna Hacho1 ${ }^{1 *}$, Elżbieta Bondar-Nowakowska ${ }^{1}$, Ewa Nowakowska ${ }^{3}$ \\ ${ }^{1}$ Institute of Environmental Protection and Development, Wrocław University of Environmental and Life Sciences, \\ Wrocław, Poland \\ ${ }^{3}$ Researcher Institute of Computer Science, Polish Academy of Sciences, Warsaw, Poland
}

Received: 14 September 2017

Accepted: 11 February 2018

\begin{abstract}
The aim of this study was to determine the link between the elements of a riverbed system (river length, longitudinal profile, bottom width, river bed depth, bank slope, bank protection, bottom substrate, and level of silt build-up), modified by regulatory and maintenance work, the number of aquatic vascular plant species, and their evenness present in both small and medium lowland streams in Poland.

100 study sections were analysed in 29 watercourses. Due to their geological, hydromorphological, and climate settings, the examined watercourses are representative of the central European plains, of which 65 sections are located in regulated and maintained watercourses and 35 are in unmodified streams. The Shapley value regression method was used to establish the influence of the stream features on aquatic plants.

Results identified 27 different macrophyte taxa, where the most frequently occurring were Sparganium emersum Rehmann, Phalaris arundinacea L., and Lemna minor L. The results found that aquatic plant communities were influenced by the analysed factors, regardless of whether a watercourse was shaped by technical means or not. The most influential parameters were the level of silt build-up and bottom width. Furthermore, results brought to evidence that watercourses are complex systems where elements are linked by a series of relationships and that single correlations among environmental elements, anthropogenic interactions, and aquatic plants are very rare.
\end{abstract}

Keywords: aquatic vascular plants, environmental factors, macrophytes, river regulation, maintenance works

\section{Introduction}

Rivers flowing through valleys constitute one of the most diversified ecological systems with one of the highest indexes of biological production, species variety,

*e-mail: justyna.hachol@upwr.edu.pl and abundance of living organisms. Simultaneously, they are frequently subjected to strong anthropogenic activity $[1,2]$. Each and every form of interference of a watercourse's stream bed has an effect on its biocoenosis [3, 4]. Regulatory works such as channel resectioning, bank reprofiling, channel deepening, channel widening, and the protection of river banks - as well as sometimes unnecessary or overambitious 
maintenance works - can all contribute to a reduction in the amount of natural variation normally found in a riverbed. These forms of technical interference are performed mainly to protect a valley from flood and drought. However, such works can lead to changes in the hydraulic characteristics of a river [5]. Their consequences can interfere with the existing dynamic balance in the stream and surrounding environment, resulting in numerous environmental threats [6].

Regulatory and maintenance works have both direct and indirect impacts on the biocoenosis of riverbeds [7]; a direct impact can stem from the adopted technical and technological solutions used during engineering works, while an indirect influence can originate from accepted design solutions. The indirect outcomes of water works on water biocoenosis include changes in water flow velocity, water levels, and the type of stream bed material [8]. Yet such works or modifications can cause the formation of diversified ecosystems with different structures and functions, such as both above and below a dam [9]. Regulatory and maintenance works are frequently linked with the necessity of excess vegetation growth removal from river banks and littoral zones. Such modifications can produce alternate conditions for the development of water organisms [10, 11].

One of the most sensitive organisms found in stream beds on technical interference are vascular aquatic plants. These aquatic plants are one of many biological components that are assessed when determining the ecological status of a water body [12]. They have autochthonous characteristics providing organic matter to the water ecosystem. They create suitable environmental conditions as well as influence the watercourse's hydrochemistry. They create habitats for other water organisms, have a beneficial impact on a watercourse's ability to self-purify, decrease the intensity of water erosion, and promote substrate stabilization
[13-15]. Simultaneously, aquatic plants also play a role in engineering river channels [16]. Well-developed plant networks are used to elevate water levels to decrease the hydraulic throughput of a riverbed. As such, they can affect the flow velocity, sediment dynamics and, consequently, the development of habitats [17].

During periods of heavy rainfalls aquatic plant development is favoured, which may constitute a danger of flooding to adjacent areas and cause scarp landslides. During low flow periods, strongly developed plants may as well result in the deterioration of oxygen balance in a river due to decay processes caused by the decomposition of dead plant remains occurring in the bottom [15]. This influences the deterioration of ecological quality of the watercourse.

Assessing the impact of environmental factors on aquatic biodiversity has become an important research objective in river management [18]. This applies to both aquatic fauna [19-22] and flora [17, 23-25]. Most of the research on the development of aquatic plants in different conditions is concentrated on only a few chosen environmental elements. The most widely examined and described factors influencing water plant communities have been: flow velocity [13, 23-27], bottom substrate [23, 24, 28, 29], and degree of shading [27, 30, 31]. In many European rivers the impact of altering hydromorphology on macrophyte communities also has been investigated $[32,33]$.

Our study aims to address the question as to how sensitive to physical habitat modification aquatic vascular plants are, and how they vary with regards to the physical elements that compose a river bed system, holding a significant influence on the development of aquatic plants and simultaneously being able to be modified by regulatory or maintenance works. The following elements of the system meeting the above criteria were alleged to be crucial: river length, longitudinal profile, bottom

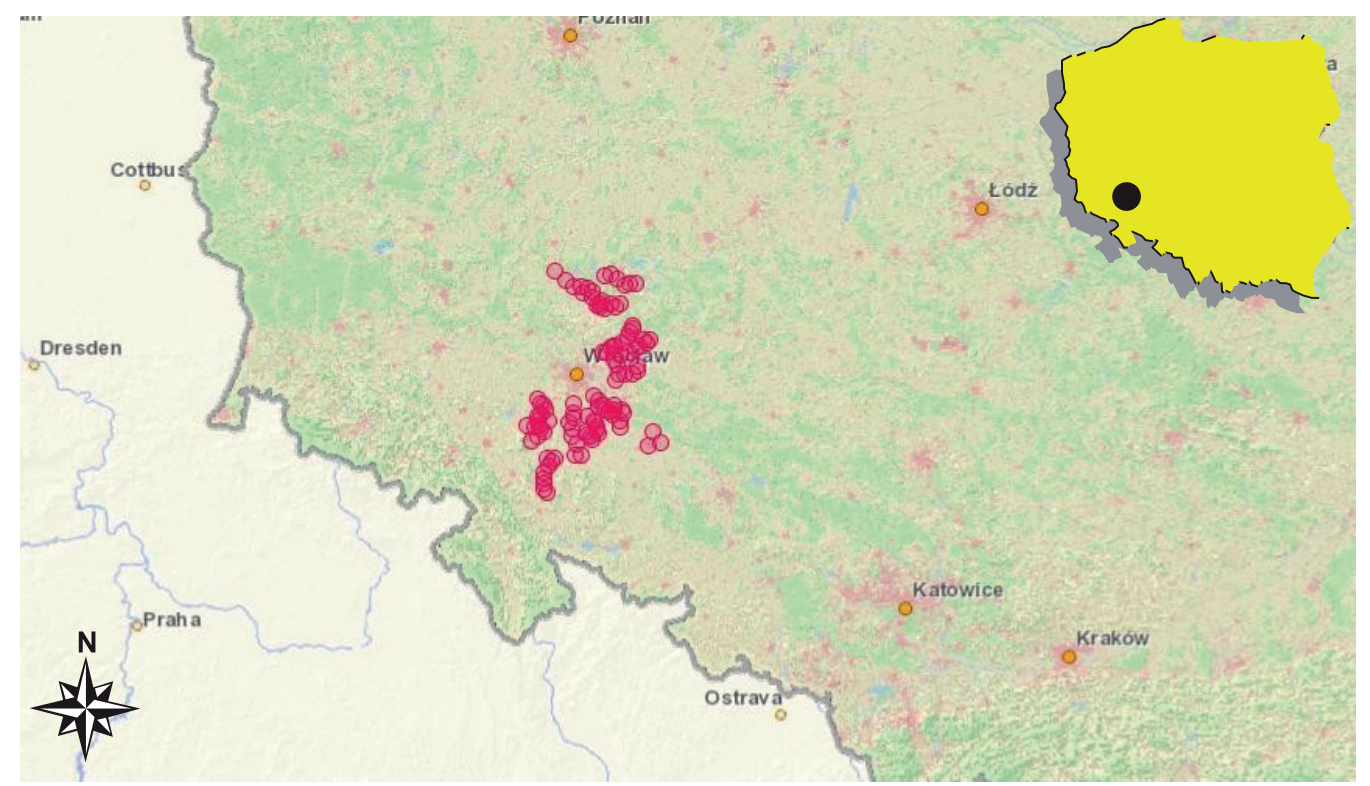

Fig. 1. Distribution of surveyed sections (developed based on http://geoportal.kzgw.gov.pl/imap/). 
width, river bed depth, bank slope, bank protection, bottom substrate, level of silt build-up, and degree of shading.

To answer the questions we determined the link and interactions between these parameters and the vascular water plant richness. We used two metrics - the number of aquatic plant species and the evenness in species distribution.

All analysed factors modify habitat conditions in rivers. However, our hypothesis is that the qualitative and quantitative state of water plants in the river bed is a function of the cumulative impact of all these elements, not individually considered factors. Therefore, watercourses should be treated as complicated and ecologically dynamic systems when studying the impact of regulatory and maintenance works on water ecosystems. Such an approach needs to treat a watercourse as a composition of linked elements forming a complicated hydrological chain.

\section{Experimental Procedures}

\section{Study Sites}

A field survey was conducted on Lower Silesian watercourses located in southeastern Poland (Fig. 1). Small (catchment area of $100-1000 \mathrm{~km}^{2}$ ) and medium (catchment area of 1000-10000 $\mathrm{km}^{2}$ ) lowland watercourses (altitudes below $200 \mathrm{~m}$ above sea level) that comprise a part of the Odra River basin were selected for study in accordance to the "System A" river typology as derived from the EU Water Framework Directive [12]. One-hundred 100-meter-long study sections were determined in 29 watercourses. All were in areas with similar climate (moderate, transition zone between maritime and continental), geology (Foresudetic Monocline, Permian Rocks, and Trias) and soil (Luvisols formed from loess and brown soil) conditions.

Due to the geological, hydromorphological, and climate characteristics, the examined waterways are representative of the lowland ecoregions found in central European highlands and plains [34, 35]. These were largely shaped by the huge ice cap of the last glacial period and consist mainly of glaciofluvial deposits, with most of the remaining sediment consisting of sand. Central European river basins are rarely underlain by solid bedrock. Hence, there is a high infiltration capacity following precipitation and typically little seasonal variation in river discharge [35]. These streams are characterised by low average flow velocities and low hydrological variability. Therefore, the obtained results of the following research may be related to other smalland medium-sized central European rivers.

Rivers with anthropogenic alteration process, both regulatory and maintenance works, were studied, totaling 65 sections. The type of regulatory work was most often channel deepening, changes to the bank slope, and bank reinforcement using fascine installation,
Table 1. Number of study sections in regulated and maintained watercourses.

\begin{tabular}{|c|c|c|}
\hline \multirow{2}{*}{$\begin{array}{c}\text { Type of } \\
\text { watercourse } \\
\text { works }\end{array}$} & \multicolumn{2}{|c|}{ Number of study sections } \\
\cline { 2 - 3 } & Time elapsed since technical interference \\
\cline { 2 - 3 } & $>10$ years & $<10$ years \\
\hline Regulatory & 10 & 20 \\
\hline Maintenance & 0 & 35 \\
\hline
\end{tabular}

rock riprap, gabion retaining walls, or concrete elements. Stabilization conservation work usually comprised manual bank mowing, mechanical elutriation with the removal of aquatic plants, and the stabilization of side banks using fascine installations. The study sections that were a part of the altered watercourses were quantified into two groups (Table 1). The first group comprised sections where technical interference was performed no longer than 10 years in relation to the research period, while the second group included sections where more than 10 years had elapsed from the completion of the work to the time when field research was conducted. Information on the date of when the works were completed was obtained from the responsible authorities for the watercourses. The remaining 35 study sections were located in the same watercourses, in their parts that featured no technical interference.

A field survey was conducted in the vegetative periods (July-August), between 2010 and 2013, after several days of stable hydrological conditions [36].

\section{Water Quality}

In each section, chemical analysis of water quality was performed. Water samples of $1 \mathrm{dm}^{3}$ were taken from the river stream threefold. The measure involved six parameters: $\mathrm{pH}$, dissolved oxygen, ammonia, nitrites, nitrates, and phosphates. Measurements were carried out directly in the field. The reaction was measured by the potentiometric method using a SLANDI pH204 $\mathrm{pH}$-meter. Other chemical analyses of water were made using a SLANDI LF300 photometer. Analysis was conducted for the duplicate samples using standard reagents.

Based on the results of water measures in every section, waters were qualified into one out of three water quality classes. Chemical analyses were performed to exclude sections with high trophic contamination influencing quality and quantity of water plants. Although results of the research constituted only a background of further analyses, they were not included in this paper.

\section{Hydromorphological Survey}

In each study section, a detailed inventory of several parameters that compose a watercourse system was performed. These elements included river length, bottom slope, bottom width, watercourse depth, bank slope, type 
Table 2. Assessment scale used to determine the type of bank protection and bottom substrate.

\begin{tabular}{|c|c|c|}
\hline $\begin{array}{c}\text { Assessment } \\
\text { scale }\end{array}$ & Bank protection & Bottom substrate \\
\hline 1 & None & Organic \\
\hline 2 & Fascine installations & Sand \\
\hline 3 & Stone coating, gabions & Gravel/stone \\
\hline 4 & Concrete elements & Concrete elements \\
\hline
\end{tabular}

of bank protection, type of bottom substrate, level of silt build-up, and the amount of shade cast by riparian vegetation.

The length of each watercourse was measured from source to the study section based on 1:50000-scale topographical maps. The measurements of bottom width, depth, bank slope, longitudinal profile, and the level of silt build-up were conducted in the field in cross-sections spaced every $10 \mathrm{~m}$. Subsequently, the average values of these factors for the whole section were then calculated. The type of bank protection and the bottom substrate that composed the whole study section was also noted. These two factors were evaluated by a 4-point scale used to assess the type of material used and how much it differed from an unmodified natural watercourse (Table 2). An assessment of the degree of shading was made visually by standing in the water bed at a point halfway of the total study section. A 5-degree scale assessing the degree of shade cast on the test section was selected, where 0 denotes no shade, 1 - little shade, 2 - medium shade, 3 - high shade and 4 - the section is entirely shaded [38].

\section{Aquatic Plants Survey}

The analysis was based on fieldwork using the WFD macrophyte method for river assessment [36], which is implemented for floral monitoring in Poland. Floral examination consisted of identifying the aquatic vascular plants found in the study sections and determining their cover. All aquatic vascular plants that were rooted in the water, floating on the water surface, or under it for at least $90 \%$ of the vegetative period were considered. The identification of water plant species was conducted manually by wading on the river bed from one bank to the other. Rakes were used for picking up plant life in places where access was difficult. All the vascular aquatic plants were identified to the species level except for Callitriche, which was identified to the genus level. The 9-point scale devised by Szoszkiewicz et al. [36] was used to determine the abundance of each species.

\section{Data Analysis}

We calculated an evenness index (E) based on Pielous's evenness index [39]. The index was calculated as:

$$
J=\frac{H}{H_{\max }}
$$

...where:

$H$ - the number derived from the Shannon diversity index $H_{\max }$ - the maximum value of $\mathrm{H}$, calculated as:

$$
H_{\max }=\operatorname{In} \mathrm{S}
$$

...where:

$S$ - the total number of aquatic vascular plant species.

The data obtained during our field study defined a set of diversified parameters in both longitudinal and cross-sections of the study sections, including bottom substrate, bank protection methods, and the amount of shade cover. To assess the influence of these elements on aquatic vascular plant communities, statistical analysis was performed, where the major gradients of the factors and two metrics (the number of aquatic plant species and the evenness in species distribution) were first analysed separately for the unmodified, maintained, and regulated study sections, including the KruskalWallis test, using Statistica v. 12 software. Additionally, constrained ordination analysis was used to visualize the relationships between the unmodified, maintained, and regulated study sites and their physical characteristics in the context of the number of aquatic plant species and evenness.

Regression analysis was then performed where the basis for analysis constituted a model where the explanatory variables were the elements of a watercourse's bed, while the response variable was the number of aquatic plants species. The $\tau$-Kendall correlation coefficient was then calculated for all variables. The calculated coefficients allow for associations to be determined among the variables by presenting them in ordinal scales with tied ranks.

To establish the influence of the abiotic factors of the river bed on the number of aquatic plants species we used the Shapley value regression (SVR) method, dedicated to modelling with multicollinearity. This method is based on the concept of cooperative game theory by using the Shapley value [40]. When applied to regression modelling, it provides reliable estimates of the individual contribution of each predictor on the prediction of the target variable as given by the model [41]. In multicollinearity, information on the individual contribution of each predictor cannot be derived from classical linear regression. In other words, high correlations between the explanatory variables may not affect the predictive power of the model, but the individual coefficients do not reflect the predictor's contribution in such a setup [42, 43].

For the considered data, multicollinearity originated from two sources. First, it stemmed from the natural correlation between some of the parameters. Second, some of the features only had an ordinal character and their impact cannot be assumed to be linear (e.g., level of silt build-up). Therefore, the need to recode them as binary dummy variables in order to capture their impact 


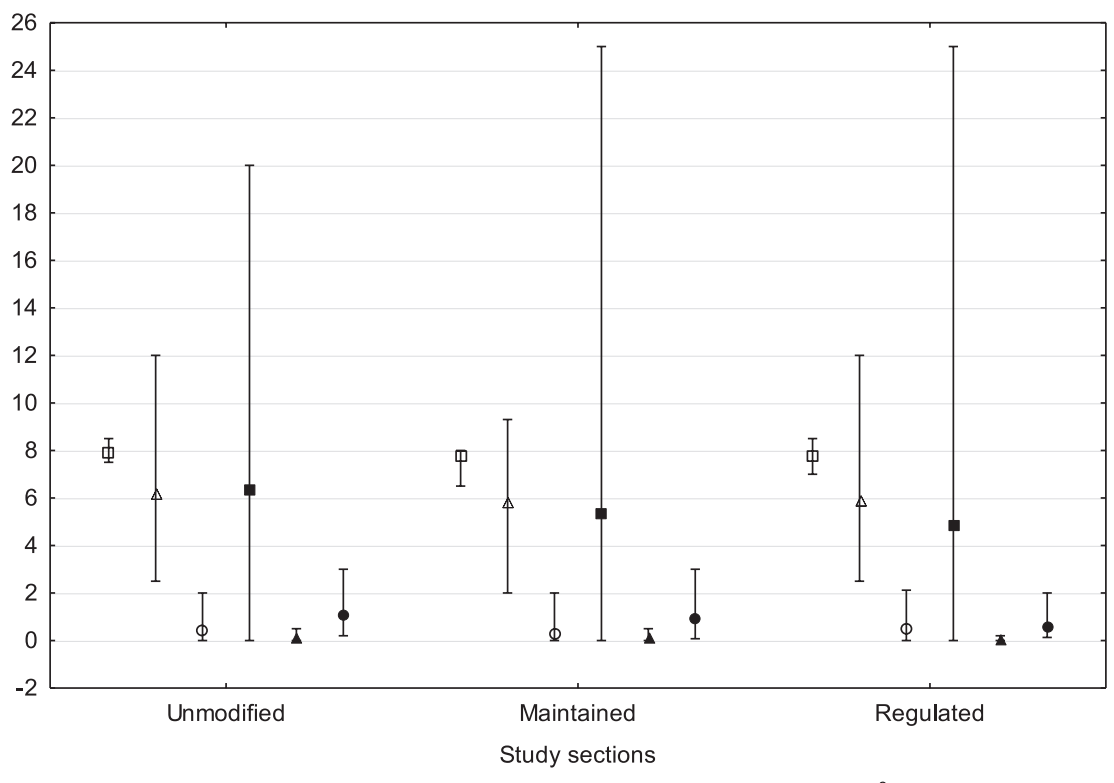

平 $\mathrm{pH}$, 平 dissolved oxygen, $\Phi \mathrm{NH}_{4}{ }^{+}$, 平 $\mathrm{NO}_{3}^{-}$, 互 $\mathrm{NO}_{2}^{-}$, 互 $\mathrm{PO}_{4}{ }^{3-}$

Fig. 2. Box-Whisker plots for the average, minimum, and maximum values of chemical and physical indicators of water quality in unmodified, maintained, and regulated watercourses.

on the target variable emerged. Even with the reference category omitted (to avoid structural dependences), the dummy variables introduced additional multicollinearity as their categories were mutually exclusive. The individual importance for each dummy-coded explanatory variable was obtained as a sum over the importance of the corresponding dummies. Dummy recoding was applied to the level of silt build-up, bottom substrate, bank slope, bank protection and the degree of shading. Other aspects were directly included in the model (whether unmodified or altered, watercourse length, longitudinal profile, and bottom width).

\section{Results}

Water Quality and Hydromorphological Survey

The values of chemical and physical indicators of water quality in river beds unmodified and altered as a result of regulatory and maintenance works (Fig. 2) are similar in all groups of study sections. Therefore, it can be considered that in this case water quality is not a decisive factor influencing aquatic vascular plants.

The minimum, maximum, and average values of analysed hydromorfological parameters were presented

Table 3. Minimum, maximum, and average values of analysed parameters in the unmodified and modified study sites.

\begin{tabular}{|c|c|c|c|c|c|c|c|c|c|}
\hline \multirow{2}{*}{ Parameter } & \multicolumn{3}{|c|}{$\begin{array}{l}\text { Unmodified } \\
\text { study sections }\end{array}$} & \multicolumn{3}{|c|}{$\begin{array}{l}\text { Maintained } \\
\text { study sections }\end{array}$} & \multicolumn{3}{|c|}{$\begin{array}{c}\text { Regulated } \\
\text { study sections }\end{array}$} \\
\hline & Min. & Max. & Average & Min. & Max. & Average & Min. & Max. & Average \\
\hline $\begin{array}{c}\text { Bottom } \\
\text { Width, m }\end{array}$ & 0,80 & 8,00 & 3,34 & 1,00 & 10,00 & 3,56 & 1,00 & 12,00 & 4,27 \\
\hline Watercourse depth, m & 0,50 & 3,50 & 1,72 & 1,00 & 3,50 & 2,00 & 0,60 & 3,00 & 1,92 \\
\hline $\begin{array}{c}\text { Bottom } \\
\text { slope, \%o }\end{array}$ & 0,10 & 3,50 & 1,20 & 0,20 & 4,20 & 0,99 & 0,20 & 4,30 & 1,07 \\
\hline $\begin{array}{l}\text { Bank } \\
\text { Slope }\end{array}$ & $1: 0,5$ & $1: 3,5$ & $1: 2$ & $1: 0,5$ & $1: 3$ & $1: 1,5$ & $1: 0,2$ & $1: 2$ & $1: 1,5$ \\
\hline Level of silt build-up, $\mathrm{cm}$ & 0,00 & 55,00 & 10,50 & 0,00 & 25,00 & 9,68 & 0,00 & 50,0 & 9,31 \\
\hline $\begin{array}{c}\text { Shading } \\
\text { degree }\end{array}$ & 0 & 4 & 1 & 0 & 4 & 1 & 0 & 4 & 1 \\
\hline Type of bank protection & \multicolumn{3}{|c|}{ No bank protection } & \multicolumn{3}{|c|}{ No bank protection or fascine } & \multicolumn{3}{|c|}{$\begin{array}{l}\text { None, fascine, stone coating, } \\
\text { gabions, concrete elements }\end{array}$} \\
\hline Type of bottom substrate & \multicolumn{3}{|c|}{$\begin{array}{l}\text { Organic, sand, gravel and } \\
\text { stones }\end{array}$} & \multicolumn{3}{|c|}{$\begin{array}{c}\text { Organic, sand, gravel and } \\
\text { stones }\end{array}$} & \multicolumn{3}{|c|}{$\begin{array}{c}\text { Organic, sand, gravel, stones, } \\
\text { concrete }\end{array}$} \\
\hline
\end{tabular}


Table 4. Frequency of aquatic plants in the studied sites.

\begin{tabular}{|c|c|c|}
\hline \multirow{2}{*}{ Aquatic plant species } & \multicolumn{2}{|c|}{$\begin{array}{l}\text { Number of study sections } \\
\text { featuring the species }\end{array}$} \\
\hline & Unmodified & Modified \\
\hline Alisma plantago-aquatica $\mathrm{L}$. & 2 & 3 \\
\hline Berula erecta (Huds.) Coville & 8 & 10 \\
\hline Butomus umbellatus L. & 2 & 4 \\
\hline Callitriche L. & 4 & 18 \\
\hline Ceratophyllum demersum $\mathrm{L}$. & 1 & 4 \\
\hline Elodea canadensis L. & 5 & 12 \\
\hline $\begin{array}{c}\text { Glyceria maxima (Hartm.) } \\
\text { Holmb. }\end{array}$ & 11 & 23 \\
\hline Hydrocharis morsus ranae $\mathrm{L}$ & 0 & 2 \\
\hline Iris pseudacorus L. & 1 & 0 \\
\hline Lemna minor L. & 13 & 28 \\
\hline $\begin{array}{l}\text { Myosotis palustris (L.) L. em. } \\
\text { Rchb. }\end{array}$ & 3 & 1 \\
\hline Nuphar lutea (L.) Sibth. \& Sm. & 3 & 4 \\
\hline Oenanthe aquatica (L.) Poir. & 0 & 2 \\
\hline Phalaris arundinacea $\mathrm{L}$. & 16 & 25 \\
\hline Phragmites communis Trin. & 7 & 17 \\
\hline $\begin{array}{c}\text { Polygonum amphibium L. f. } \\
\text { natans Moench }\end{array}$ & 0 & 1 \\
\hline Potamogeton crispus L. & 2 & 2 \\
\hline Potamogeton filiformis Pers. & 1 & 3 \\
\hline Potamogeton natans L. & 0 & 2 \\
\hline Potamogeton pectinatus $\mathrm{L}$. & 2 & 3 \\
\hline Ranunculus fluitans Lam. & 1 & 2 \\
\hline Sagittaria sagittifolia L. & 9 & 15 \\
\hline $\begin{array}{c}\text { Sparganium emersum Reh- } \\
\text { mann }\end{array}$ & 15 & 27 \\
\hline $\begin{array}{c}\text { Sparganium erectum L. em. } \\
\text { Rchb. s.s. }\end{array}$ & 4 & 1 \\
\hline $\begin{array}{l}\text { Spirodela polyrrhiza (L.) } \\
\text { Schleid. }\end{array}$ & 2 & 6 \\
\hline Typha angustifolia $\mathrm{L}$. & 7 & 17 \\
\hline Veronica beccabunga L. & 3 & 3 \\
\hline
\end{tabular}

in Table 3. The width of the watercourse bottoms in study sections ranged from $0,8 \mathrm{~m}$ to $8,0 \mathrm{~m}$ in the unmodified and from $1,0 \mathrm{~m}$ to $12,0 \mathrm{~m}$ in the altered watercourses. The depth ranged from $0,5 \mathrm{~m}$ to $3,5 \mathrm{~m}$ in unmodified study sections. In the regulated and maintained sections the values were similar, with minimum depth $0,6 \mathrm{~m}$ and maximum $3,5 \mathrm{~m}$. The bottom slope was between $0,1-3,5 \%$ in unmodified and $0,2-4,3 \%$ in altered watercourses. All the study sections showed a wide range of values of the bank slope. There were both vertical slopes and sections with flat and irregular slopes. In study sections, five different bottom substrates were observed with organic substrate, sand, gravel, stones, and concrete elements. However, the concrete elements were only in regulated watercourses. The level of sludge accumulation ranged from 0 to $55 \mathrm{~cm}$ in unmodified and to $50 \mathrm{~cm}$ in altered study sections. All shading stages were registered, from complete lack to total shading.

\section{Aquatic Plants Survey}

In total, 27 taxa of aquatic vascular plants were found in the 100 study sites (Table 4). The data shown in Table 4 suggests that the most frequently occurring aquatic plants were Sparganium emersum Rehmann, Phalaris arundinacea L., and Lemna minor L. They were present in about $40 \%$ of the study sections in both unmodified and altered watercourses. In most study sites these species occurred frequently, forming dense phytocenosis. Less common, in only $20-30 \%$ of the study sections, were
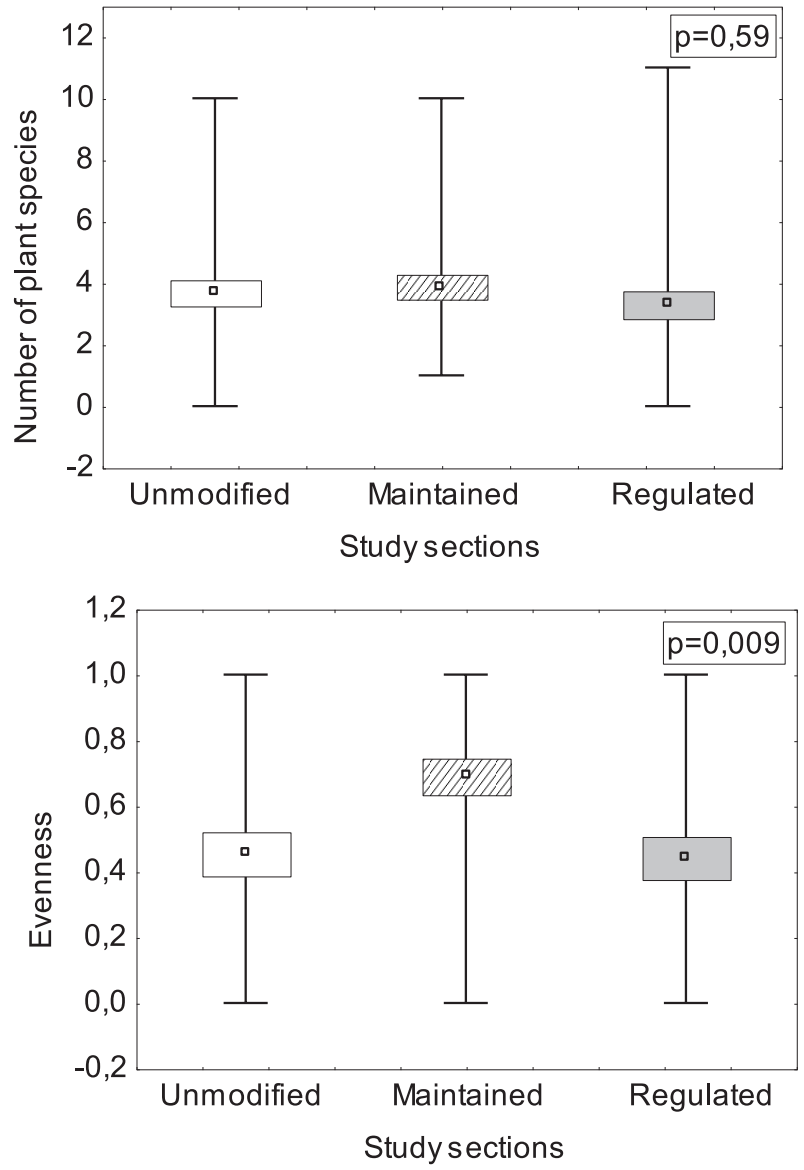

Fig. 3. Box-Whisker plots representing the differences in the unmodified, maintained, and regulated watercourses by the number of aquatic vascular plant species and evenness; squares denote the average, boxes denote average \pm standard error, and whiskers denote minimum and maximum values; $p$ signifies p-value calculated using the Kruskal-Wallis test. 

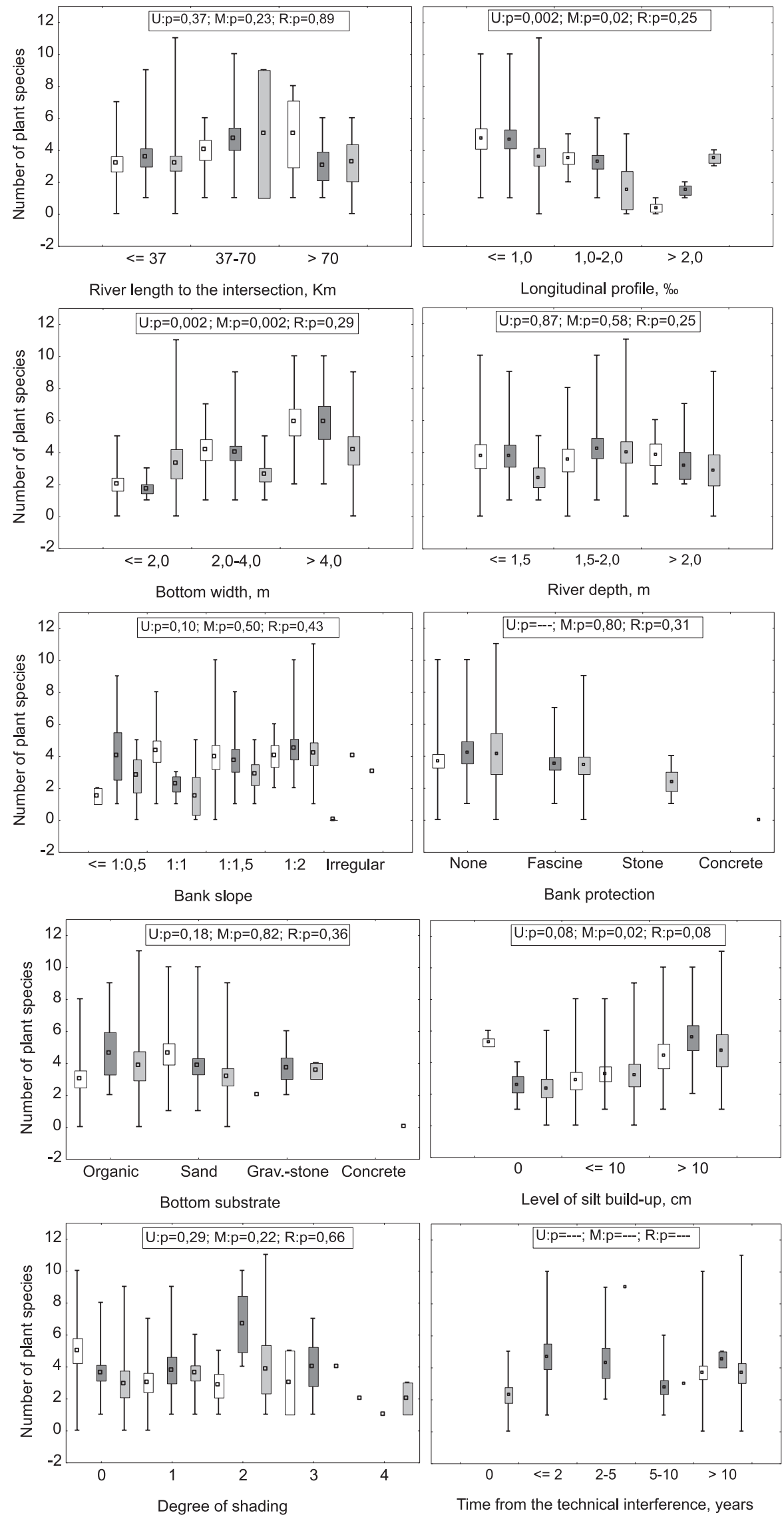

Fig. 4. Box-Whisker plots for the differences in unmodified (white boxes), maintained (black-white boxes), and regulated (grey boxes) watercourses in terms of the number of aquatic vascular plant species according to the values of analysed factors; squares denote average values, boxes denote average \pm standard error, and whiskers denote the minimum and maximum values; p-values for unmodified (U), maintained (M), and regulated (R) study sections, calculated using the Kruskal-Wallis test, are shown in the boxes. 
Glyceria maxima (Hartm.) Holmb., Sagittaria sagittifolia L., Phragmites communis Trin., Typha angustifolia L., and Callitriche sp. Other species occurred rarely or sporadically. Four species, Hydrocharis morsus ranae L., Oenanthe aquatica (L.) Poir., Polygonum amphibium L. f. natans Moench, and Potamogeton natans L., were only observed in watercourses where technical works had once been performed. The species Iris pseudacorus L. was observed only in natural riverbeds. Although Myosotis palustris (L.) L. em. Rchb. and Sparganium erectum L. em. Rchb. s.s. occurred in all groups of watercourses, they were observed more often in unmodified study sections than in altered ones. The obtained data indicated that the plants with the most cover belonged to the most abundant species. The remaining species were represented only by a few individuals, resulting in low cover.

The research indicated that the number of aquatic plant taxa observed in the study sites was diversified, with values ranging from 0 to 11 . The average number of taxa was 3,7 in unmodified, 3,9 in maintained, and 3,3 in the regulated watercourses (Fig. 3). In addition, we found no significant differences between the unmodified and altered study sections ( $p$-value $>0,05$ ). However, we found significant differences in case of the evenness index ( $p$-value $<0,05$ ). The average value of the evenness was 0,45 for the unmodified, 0,69 for maintained, and 0,44 for the regulated watercourses (Fig. 3). This may be attributed to the fact that this index also takes plant cover into account.

\section{Linkages between Aquatic Plants and Physical Characteristics of the Riverbed}

To explain if any of the considered elements of a riverbed system influenced aquatic plants, we used statistical analyses, including the Kruskal-Wallis test. Since evenness index is correlated with the number of taxa, only the analyses on the number of taxa were presented in Fig. 4.

We did not find any significant relationship between river length to the intersection and the number of aquatic plant species ( $p$-values $>0.05$ ). However, we found a significant relationship between the number of aquatic plant species and longitudinal profile in both unmodified and maintained study sections ( $p$-value < 0.05) (Fig. 4). The highest average number of species was found in unmodified sections with a $\leq 1.0 \%$ o slope. Analysis also found that in both watercourse groups a decline of the longitudinal profile value was tied to an increase in the number of species. In the regulated watercourses, there were no significant relationships to note (Fig. 4). The results found that an increase in the bottom width was tied to a rise in the number of water plant species in unmodified and maintained study sections ( $p$-values $<0.05$ ). In the regulated watercourses, we did not find any significant relationships between these two parameters. Considering the obtained results, the depth of the riverbed had no influence on the number of species ( $p$-values $>0.05)$. Additionally, watercourses subjected to technical interference and those left untouched had a similar average number of species occurring in studied depth ranges. The sections in all the watercourses showed no correlation between the number of species and bank slope. In unmodified study sections changes in the number of species in terms of riverbanks with different slopes were more significant than in the sections located in altered watercourses. The highest average number of water plant species was found in watercourses where maintenance work was performed but without any bank protection. However, there was no significant correlation between bank protection type and the plant metric.

In unmodified, natural watercourses, the highest number of species occurred in sections with a sandy bottom substrate, while fewer were found in watercourses that had a gravel or stony substrate. In altered sections, the influence of the bottom substrate on the number of species was less noticeable. In unmodified watercourses, the highest average number of water plant species was observed in sections with a silt layer up to $10 \mathrm{~cm}$ thick. From the current study results showing that in regulated and maintained sections the number of species increased, there were those where there was an increase in silt thickness. Only in the maintained study sections were the relationships statistically significant.

Similar tendencies were observed for the evenness index. In the unmodified study sections we found a statistically significant relationship between the index and only two physical characteristics: longitudinal profile and level of silt build-up ( $p$-values $<0.05$ ). In the modified study sections we did not find any significant relationship between analysed characteristics.

We used constrained ordination analysis to visualize the relationships between the unmodified, maintained, and regulated study sites and their physical characteristics in the context of the number of aquatic plant species and evenness. This is based on the results of a variant of canonical correlation analysis implemented by the RDA function of the 'vegan' $\mathrm{R}$ package. The plot presented in Fig. 5 shows the sites on the RDA plane with shape indicating the types of investigated study sections (unmodified, maintained, and regulated), and the overlaying biplot showing the considered characteristics. The highest positive contribution to the first axle (RDA1) was longitudinal profile and negative - bottom width while for the second axis (RDA2) the highest positive contribution was the level of silt buildup and negative - bottom substrate. However, there is no visible pattern among the points and their shape distribution (Fig. 5).

Based on presented results, we cannot directly state what influence the watercourse elements have on the number of species in vascular water plant communities. Hence, this was the reason why regression analysis was later used. In order to pick the regression approach properly accounting for the relationships existing in the data and providing a reliable estimate of the overall influence of the factors considered, the structure of associations between the variables that make up the model 


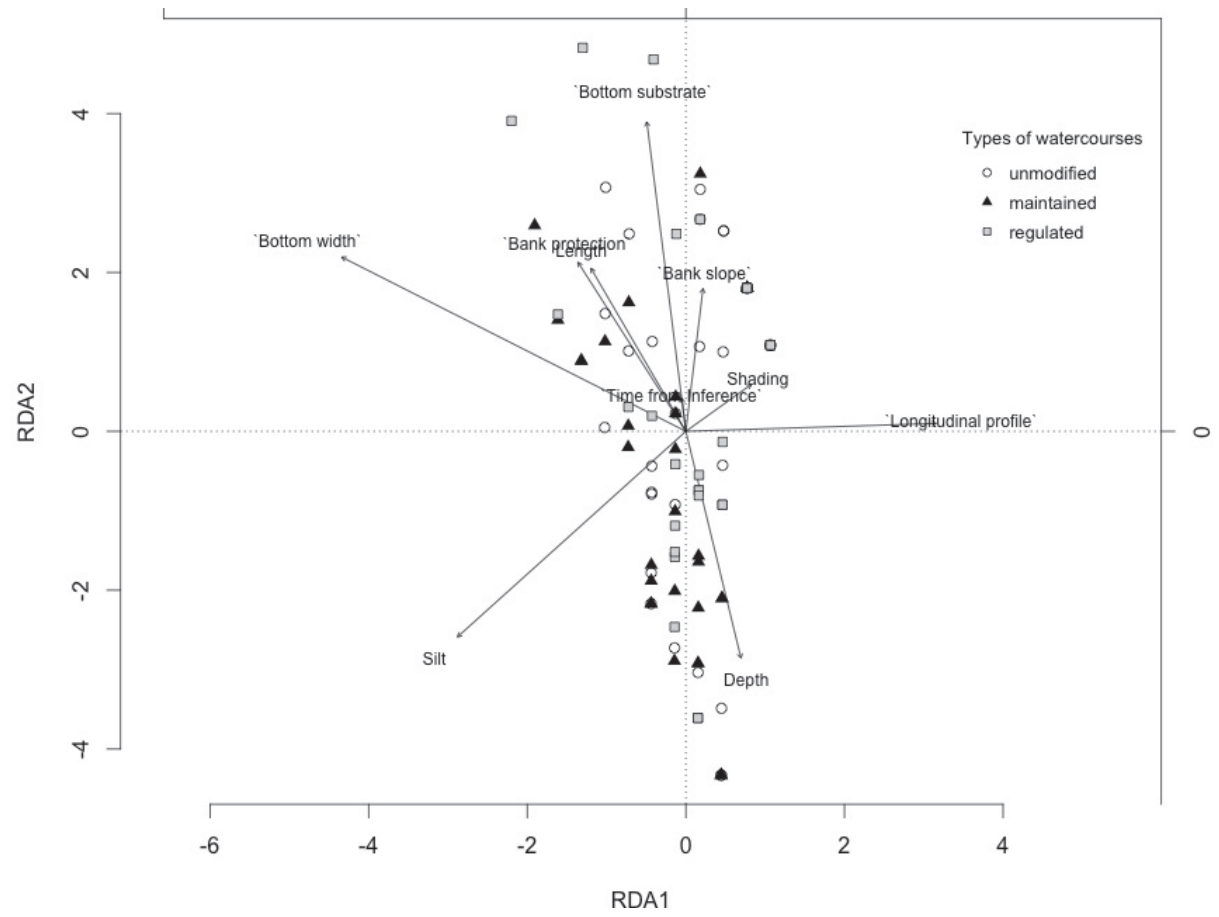

Fig. 5. RDA ordination graph for the first two axes for the dataset of the study sites described by the 10 considered characteristics and the aquatic plant metrics (the number of plant species and evenness) as constraining variables.

had to be analysed. Fig. 6 presents a map with the marked $\tau$-Kendall correlations. This is a heatmap where colors reflect the strength of the correlation between each pair of intersected variables, while the overlaid topographical lines additionally indicate the areas of similar strength relationships. For example, although we can see that the bottom width relatively strongly correlates with the number of species, its correlation with the river length creates an even higher, isolated peak. In general, the occurrence of the area corresponding to associations above 0.4 and below -0.4 indicates that some of the considered parameters are quite strongly correlated. Simultaneously, associations between these parameters

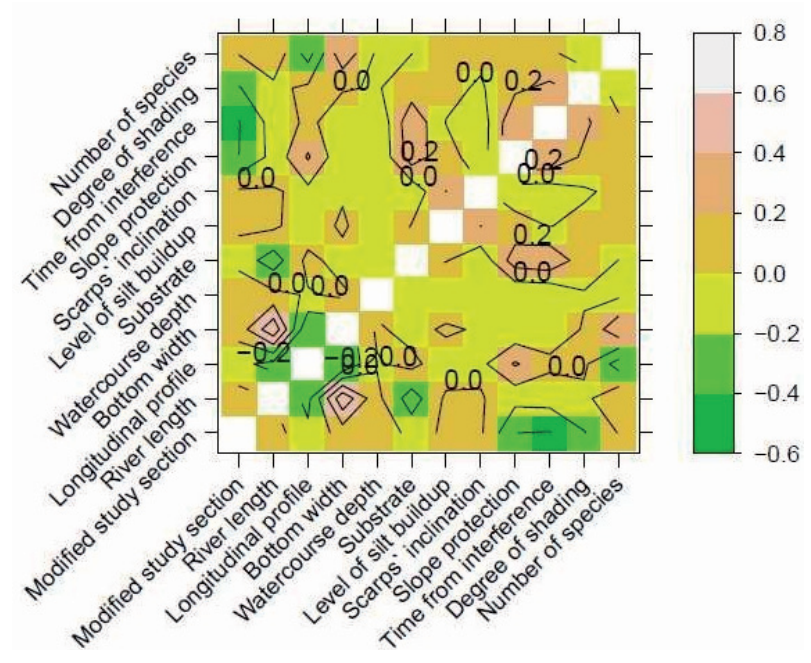

Fig. 6. $\tau$-Kendall correlation map. and the number of water plant species were at the same value level as the associations among the parameters. These two facts indicate that, in this case, we should not consider the effects of the specific parameters based on a classical linear regression model. Hence, this was why the SVR method was used to analyse the influence of the elements on the number of species.

The performed analysis indicates that the number of vascular aquatic plants in both small and medium lowland watercourses is only party modified by the group of the 10 riverbed elements that were examined. The following elements comprise regulatory and maintenance works: length of the watercourse to the study section, longitudinal profile, width and depth of the riverbed, bottom substrate, sludge load, bank slope, type of bank protection, and the degree of shading. The total effect of these factors amounted to 54\% (RDA analysis). The remaining $46 \%$ comes from factors that were not taken into consideration in this study.

Among the elements of the watercourse system, the strongest effect on the number of species was the level of silt build-up, at $28 \%$, and the width of the bottom, at $25 \%$. The results of the study indicate that with an increase in the parameters that define these elements influenced water plant species, hence their proliferation. Statistical analyses found similar tendencies with regards to length, bank slope, and bank protection. However, an increase of the other elements - i.e., bottom slope, watercourse depth, and degree of shading - showed a decrease in the number of species occurring in the watercourse.

Fig. 7 presents the occurrence of two most common species in the analysed watercourses: S. emersum and 
$P$. arundinacea in the unmodified and altered study sections, depending on the level of the silt build-up (Fig. 7a) and the bottom width (Fig. 7b). In the unmodified study sections $S$. emersum most often was found in sections with no silt on the bottom. P. arundinacea preferred watercourses with the level of the silt buildup greater than $10 \mathrm{~cm}$ and the watercourses without the silt. In the modified (regulated and maintained) watercourses the number of study sections where $S$. emersum or $P$. arundinacea were found increased with an increase in the level of the silt build-up (Fig. 7a). In both watercourses groups unmodified

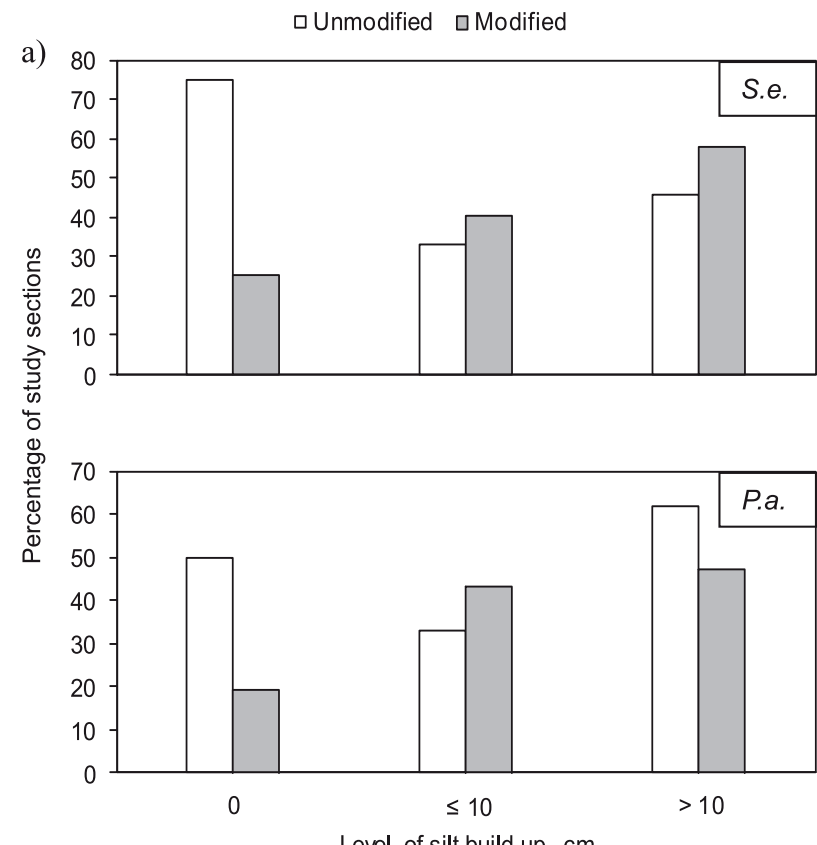

b)

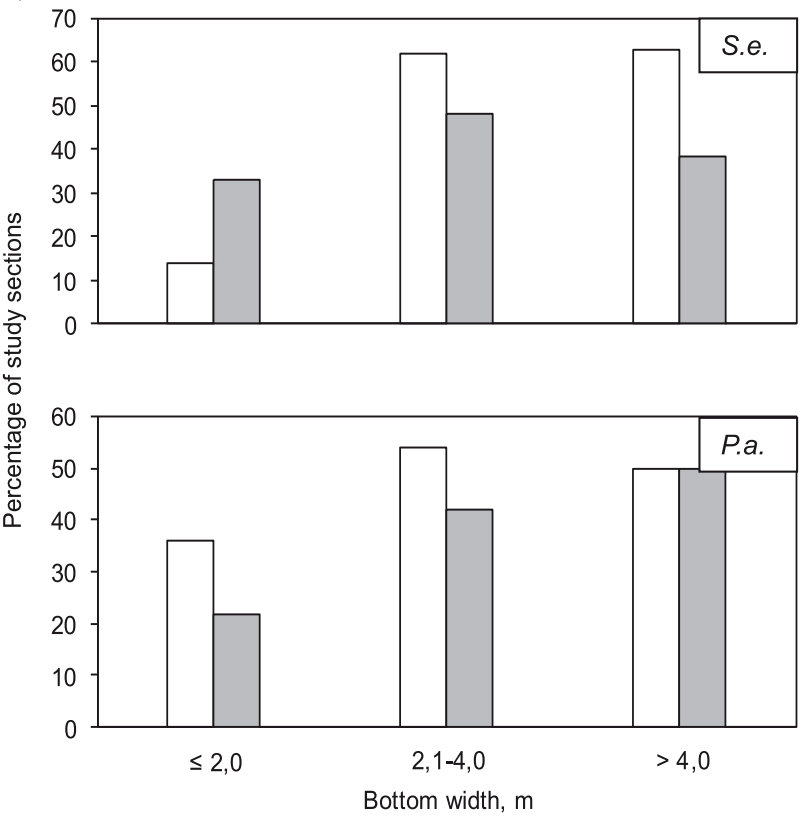

Fig. 7. Percentage of unmodified and modified study sections where $S$. emersum (S.e.) and P. arundinacea (P.a.) were found in each range of the level of silt build-up a), and in each bottom width b). and modified as a result of technical interference by $S$. emersum and $P$. arundinacea occurred most often in study sections with bottom width greater than 2,0 m than in the narrower watercourses (Fig. 7b).

\section{Discussion of Results}

We found that aquatic plants were partially influenced by the examined factors regardless of whether they were present in modified watercourses by technical interference or not. The variability in abundance and diversity of aquatic plants in unmodified rivers was highlighted by Baattrup-Pedersen et al. [44], who notice macrophyte assemblage patterns varied considerably among the main watercourse types. Based on the conducted research and analyses, the influence of nine elements of a watercourse system on the number of vascular aquatic plants was evaluated. The strongest effects were found to be the level of silt build-up and the width of the watercourse's bottom. The number of water plant species in the examined rivers in both modified and unmodified sections was found to rise with an increase in these two parameters. Numerous studies showed that the more stable bottom and contained detritus, the higher diversity and abundance of occurring organisms $[17,45,46]$. Silt accumulation in the watercourse bottom causes an increase in bottom stabilization, which favours better rooting. It is also a rich source of nutritional components used both by plants and animals [47]. In addition, the width of a watercourse is a factor that provides many water organisms with adequate living space. The wider the watercourse, the higher potential for structural diversity at the watercourse's bottom and a higher biodiversity of water biotopes. Such conditions favour water plant development as the growth of physical heterogeneity leads to an increase in biodiversity [48]. Furthermore, wide watercourses are less shaded, thus enhancing macrophyte growth [49].

Despite the positive impact of bottom width and the level of silt built-up on the number of aquatic plant species, there were no significant correlations between these parameters and the occurrence of two species most commonly found in the study sites $(S$. emersum and $P$. arundinacea). Both species also occurred in the beds of the narrowest watercourses. In the case of silt accumulation this relationship was not obvious. In the unmodified watercourses both species occurred more frequently in sections without silt. However, in the regulated and maintained watercourses the number of study sections where $S$. emersum or $P$. arundinacea were found, they increased with an increase in the level of silt build-up. Lack of the effect of those factors on $S$. emersum and $P$. arundinacea may be because both species are very common in lowland watercourses and have a high tolerance to habitat conditions [45].

The impact of riverbed depth, although slight, can affect the number of aquatic plants species. Numerous studies indicate a strong relationship between the depth 
of a riverbed and the abundance of aquatic plants. Lorenz et al. [49] found that in lowland sites the variability of depth had the highest influence on the quantity, richness, and abundance of aquatic plants. The importance of riverbed depth as a key factor for increased diversity and abundance was also found by Chambers and Kaiff [50]. They showed that the depth and the riverbed influence the amount of light reaching the bottom of the watercourse.

The other examined factors were found to influence the number of aquatic plants to a lesser extent. Taking into account the obtained results, there were no significant correlations between river length to the intersection and the aquatic plant species. This may result from the small lengths of rivers and from the location of most of the research sections being in lower courses. Significant relationships were found between the number of aquatic plant species and longitudinal profile in both unmodified and maintained study sections. In both groups, a decline in the value of longitudinal profile caused an increase in the number of species. With an increase of bottom slope, the energy of the water flow increases. It is widely known that velocity flow is one of the most important factors limiting the development of most aquatic plants [51]. In the regulated watercourses there were no significant relationships. This proves that such strong interference in the watercourse's bed, such as regulatory works, disrupts the natural functioning mechanisms in natural watercourses. Similar responses were observed in the case of bank slope and bottom substrate. In unmodified study sections changes in the number of species in terms of different slopes were significantly higher than in the sections located in disrupted, altered watercourses. In natural watercourses, the highest number of species occurred in sections with a sandy bottom substrate. It is known that higher plants prevail in watercourses where the bottom is sandy. Coarse materials, such as gravel or stones favour the growth of algae, lichens, and bryophytes [27]. In altered sections, the influence of the bottom substrate on the number of species was less noticeable.

The current study shows that in the unmodified sections the number of species decreased in shadier areas. The availability of light is a very important factor influencing aquatic plant communities in watercourses. However, many authors justified that the impact of this factor on the development of aquatic plants is marked primarily in the zone of the watercourse to a depth of $1 \mathrm{~m}$ [27]. This may justify the fact that in watercourses subjected to technical interference, which were deeper than unmodified ones, that relationship was not observed.

In the case of one of the considered factors, the time that elapsed from technical interference in the watercourse bed, no correlation was determined between this parameter and the number of aquatic plants species. It is believed that any disturbance to the environment caused by watercourse modification is in any case quickly repaired by the regeneration of the ecosystem. The field observations in current and previous [7, 52] research revealed that plant regeneration occurred already in the first vegetative season after the works' completion, and point to the secondary succession in watercourses subjected to technical works. Similar results were obtained by, e.g., Caffrey et al. [53]. In their studies, plants removed from the riverbed regrew in 3-4 months, recreating their quantity and quality from the period before the interference. Authors tried to explain the matter in the discussion. Considering every section separately, the influence of maintenance work on species composition and plant density in the riverbed - especially in the first vegetation season after works completion is noticeable. Considering all sections together, this influence is statistically insignificant. This process was highlighted by Hearne and Armitage [54], as it is linked with the fact that most aquatic plants have a very effective mechanism of vegetative reproduction and proliferation $[27,55]$. Because of secondary succession, organisms are able to rebuild their community to a level that existed before the work was initiated. However, the creation of an aquatic community identical to the one before any technical work is rarely obtained.

Moreover, the effect of maintenance works had very little influence and the effect of regulation had no influence on the number of defined species and on their evenness. Our analysis showed no significant differences in species richness between the modified and unmodified reaches. This may have been caused by using environmentally friendly designs and methods (i.e., fascine installations). Additionally, most species were characterised by a high degree of polymorphism and phenotypic adaptive ability to changeable habitat conditions. These traits cause them to be able to adapt to watercourses with completely different characteristics $[56,57]$ and cover extensive areas in both natural and man-made freshwater ecosystems [58]. An exception is strongly altered rivers, where the material used for the bank and bottom protection were rock-filled gabions or concrete elements. We found that in these study sections the number of aquatic plant species was significantly lower than in other reaches (Fig. 4).

However, a stronger effect was demonstrated by all the analysed factors when considered as a group. Their total influence on the number of species was calculated at $54 \%$. The results confirmed the thesis that watercourses are complex systems where elements are linked by a series of relationships [33, 59-62], where the factors influencing water plant communities act synergistically, and that single correlations among individual environmental elements, anthropogenic interactions, and aquatic plants are very rare.

The remaining $46 \%$ of influence on the composition of vascular plant communities must stem from other factors that were not considered in this study or from the combination of the factors. Their identification is necessary to better understand the links between environmental factors and the biodiversity of water plant communities. This would allow researchers to predict the resistance of water plant development in particular 
conditions and may contribute to the optimization of managing flowing waters and flora in river beds.

\section{Acknowledgements}

The authors are grateful to all their colleagues and friends for help in the field surveys and for all the provided advice. We would like to thank Prof. Leszek Pływaczyk, Prof. Romuald Żmuda, and Prof. Bernard Kontny from the Faculty of Environmental Engineering and Geodesy for their comments, suggestions, and financial support.

\section{Conflict of Interest}

The authors declare that they have no conflict of interest.

\section{References}

1. POFF N.L., RICHTER B.D., ARTHINGTON A.H., BUNN S.E., NAIMAN R.J., KENDY E., ACREMAN M., APSE C., BLEDSOE B.P., FREEMAN M.C., HENRIKSEN J., JACOBSON R.B., KENNEN J.G., MERRITT D.M., O'KEEFE J.H., OLDEN J.D., ROGERS K., THARME R.E., WARNER A. The ecological limits of hydrologic alteration (ELOHA): a new framework for developing regional environmental flow standards. Freshw. Biol. 55, 147, 2010.

2. LECHOWSKA E. The Impact of Embankment Construction on Floodplain Land Use in the Context of its Influence on the Environment: a Case Study of Selected Cities in Poland. Pol. J. Environ. Stud. 26 (2), 655, 2017.

3. GURNELL A.M., CORENBLIT D., GARCÍA DE JALÓN D., GONZÁLEZ DEL TÁNAGO M., GRABOWSKI R.C., O'HARE M.T., SZEWCZYK M. A conceptual model of vegetation-hydrogeomorphology interactions within river corridors. River Res. Applic. 32, 142, 2016.

4. PETKOVSKA V., URBANIC G. Links between morphological parameters and benthic invertebrate assemblages, and general implications for hydromorphological river management. Ecohydrology 8, 67, 2015.

5. BLANCKAERT K., GARCIA X.-F., STEIGER J., UIJTTEWAAL W. Ecohydraulics: linkages between hydraulics, morphodynamics and ecological processes in rivers. Ecohydrol. 6, 507, 2013.

6. DOWNS P.W., DUSTERHOFF S.R., SEARS W.A. Reachscale channel sensitivity to multiple human activities and natural events: Lower Santa Clara River, California, USA. Geomorphology 189, 121, 2013.

7. HACHOE J., BONDAR-NOWAKOWSKA E. Tendencies in the development of hydromacrophytes after the completion of regulatory and maintenance works in a river bed. Ecol. Chem. Eng. A 19 (9), 997, 2012.

8. BAATTRUP-PEDERSEN A., GÖTHE E., RIIS T., O'HARE M.T. Functional trait composition of aquatic plants can serve to disentangle multiple interacting stressors in lowland streams. Sci. Total Environ. 543, 230, 2016.
9. BYLAK A., KUKUŁA K., PLESIŃSKI K., RADECKIPAWLIK A. Effect of a baffled chute on stream habitat conditions and biological communities. Ecol. Eng. 106, $263,2017$.

10. KÖHLER J., HACHOŁ J., HILT S. Regulation of submersed macrophyte biomass in a temperate lowland river: Interactions between shade by bank vegetation, epiphyton and water turbidity. Aquat. Bot. 92, 129, 2010.

11. CAMPOREALE C., PERUCCA E., RIDOLFI L., GURNELL A.M. Modeling the interactions between river morphodynamics and riparian vegetation. Rev. Geophys. 51, 379, 2013.

12. EUROPEAN COMMISSION. Directive 2000/60/EC. Establishing a framework for community action in the field of water policy. European Commission PE-CONS 3639/1/100 Rev 1, Luxemburg. 2000.

13. GURNELL A.M., BERTOLDI W., CORENBLIT D. Changing river channels: The roles of hydrological processes, plants and pioneer fluvial landforms in humid temperate, mixed load, gravel bed rivers. Earth-Science Reviews 111, 129, 2012.

14. AGUIAR F.C., SEGURADO P., URBANIČ G., CAMBRA J., CHAUVIN C., CIADAMIDARO S., DÖRFLINGER G., FERREIRA J., GERM M., MANOLAKI P., MINCIARDI M.R., MUNNÉ A., PAPASTERGIADOU E., FERREIRA M.T. Comparability of river quality assessment using macrophytes: A multi-step procedure to overcome biogeographical differences. Sci. Total Environ. 476-477, 757, 2014

15. 1VEREECKEN H., BAETENS J., VIAENE P., MOSTAERT F., MEIRE P. Ecological management of aquatic plants: effects in lowland streams. Hydrobiologia 570, 205, 2006.

16. GURNELL A.M. Plants as river system engineers. Earth Surf. Process. Landforms 39, 4, 2014.

17. O'HARE J.M., O'HARE M.T., GURNELL A.M., DUNBAR M.J., SCARLETTC P.M., LAIZÉ C. Physical constraints on the distribution of macrophytes linked with flow and sediment dynamics in British rivers. River. Res. Appl. 27, 671, 2011.

18. VAUGHAN I.P., DIAMOND M., GURNELL A.M., HALL K.A., JENKINS A., MILNER N.J., NAYLOR L.A., SEAR D.A., WOODWARD G., ORMEROD S.J. Integrating ecology with hydromorphology: a priority for river science and management. Aquat. Conserv. 19, 113, 2009.

19. FELD C.L., DE BELLO F., DOLÉDEC S. Biodiversity of traits and species both show weak responses to hydromorphological alteration in lowland river macroinvertebrates. Freshwater Biol. 59, 233, 2014.

20. HUGHES S.J., SANTOS J.M., FERREIRA M.T., CARACA R., MENDES A.M. Ecological assessment of an intermittent Mediterranean river using community structure and function: evaluating the role of different organism groups. Freshw. Biol. 54, 2383, 2009.

21. GARCIA X-F., SCHNAUDER I., PUSCH M.T. Complex hydromorphology of meanders can support benthic invertebrate diversity in rivers. Hydrobiologia 685, 49, 2012.

22. BOOKER D.J., SNELDER T.H., GREENWOOD M.J., CROW S.K. Relationships between invertebrate communities and both hydrological regime and other environmental factors across New Zealand's rivers. Ecohydrology 8, 13, 2015.

23. RAMBAUD M., COMBROUX I., HAURY J., MORET J., MACHON N., ZAVODNA M., PAVOINE S. Relationships between channelization structures, environmental 
characteristics, and plant communities in four French streams in the Seine-Normandy catchment. Journal of the North American Benthological Society 28, 3, 596, 2009.

24. GRINBERGA L. Macrophyte species composition in streams of Latvia under different flow and substrate conditions. Estonian Journal of Ecology 60, 3, 194, 2011.

25. FABRIS M., SCHNEIDER S., MELZER A. Macrophytebased bioindication in rivers - A comparative evaluation of the reference index (RI) and the trophic index of macrophytes (TIM). Limnologica 39, 40, 2009.

26. JANAUER G.A., SCHMIDT-MUMM U., SCHMIDT B. Aquatic macrophytes and water current velocity in the Danube River. Ecol. Eng. 36, 1138, 2010.

27. GARBEY C., THIÉBAUT G., MULlER S. An experimental study of the plastic responses of Ranunculus peltatus Schrank to four environmental parameters. Hydrobiologia 570, 41, 2006.

28. MADSEN J.D., CHAMBERS P.A., JAMES W.F., KOCH E.W., WESTLAKE D.F. The interaction between water movement, sediment dynamics and submersed macrophytes. Hydrobiologia 444, 71, 2001.

29. STEFFEN K., LEUSCHNER C., MÜLLER U., WIEGLEB G., BECKER T. Relationships between macrophyte vegetation and physical and chemical conditions in northwest German running waters. Aquat. Bot. 113, 46, 2014.

30. MIDDELBOE A.L., MARKAGER S. Depth limits and minimum light requirements of freshwater macrophytes. Freshw. Biol. 37, 553, 1997.

31. HERB W.R., STEFAN H.G. Integral growth of submersed macrophytes in varying light regimes. Ecol. Model. 168, 77, 2003.

32. STEFFEN K., BECKER T., HERR W., LEUSCHNER C. Diversity loss in the macrophyte vegetation of northwest German streams and rivers between the 1950s and 2010 . Hydrobiologia 713, 1, 2013.

33. LAIZÉ C.L.R, ACREMAN M.C., SCHNEIDER C., DUNBAR M.J., HOUGHTON-CARR H. A., FLÖRKE M., HANNAH D.M. Projected flow alteration and ecological risk for pan-european rivers. River Res. Applic. 30, 299, 2014.

34. PETERSEN R.C., GISLASON G.M. Rivers of the Nordic countries. In: Cushing C.E., Cummins K.W., Minshall G.W., ed. River and Stream Ecosystems, Elsevier, Amsterdam, 295, 1995.

35. PUSCH M., ANDERSEN H.E., BÄTHE J., BEHRENDT H., FISCHER H., FRIBERG N., GANCARCZYK A., HOFFMANN C.C., HACHOE J., KRONVANG B., NOWACKI F., PEDERSEN M.L., SANDIN L., SCHÖLL F., SCHOLTEN M., STENDERA S., SVENDSEN L.M., WNUK-GŁAWDEŁ E., WOLTER C. Rivers of the Central European Highlands and Plains. In: Tockner K., Uehlinger U., Robinson C.T., ed. Rivers of Europe, Elsevier, 525, 2009.

36. SZOSZKIEWICZ K., ZBIERSKA J., JUSIK S., ZGOŁA T. Macrophyte Method for River Assessment. A methodological manual for the assessment and classification of ecological status of running waters, based on the aquatic plants. Bogucki Scientific Publishing, Poznań. 2010.

37. THOMPSON M., HOWARTH R.J. Duplicate analysis in geochemical practice. P.1. Theoretical approach and estimation of analytical reproducibility. Analyst 101, 690, 1976.

38. SCHAUMBURG J., SCHRANZ C., STELZER D., HOFMANN G., GUTOWSKI A., FOERSTER J. Instruction Protocol for the ecological Assessment of
Running Waters for Implementation of the EC Water Framework Directive: Macrophytes and Phytobenthos. Bavarian Environment Agency, München. 2006.

39. PIELOU E.C. Population and community ecology: principles and methods. Gordon and Breach, New York. 1974.

40. SHAPLEY L.S. A Value for n-person Games. In: Kuhn H.W., Tucker A.W., ed. Contributions to the Theory of Games. Ann. Math. Stud. 28, 307, 1953.

41. LIPOVETSKY S., CONKLIN M. Analysis of regression in game theory approach. App. Stoch. Model. Bus. 17, 319, 2001.

42. MASON C.H., PERREAULT jr. W.D. Collinearity, power, and interpretation of multiple regression analysis. J. Marketing Res. 28, 268, 1991.

43. GRAPENTINE A. Managing multicollinearity. Marketing Research 9, 11, 1997.

44. BAATTRUP-PEDERSEN A., SZOSZKIEWICZ K., NIJBOER R., O'HARE M., FERREIRA M.T. Macrophyte communities in unimpacted European streams: variability in assemblage patterns, abundance and diversity. Hydrobiologia 566, 179, 2006.

45. HASLAM S.M. River Plants: The Macrophytic Vegetation of Watercourses, Forrest Text, United Kingdom. 450 pp. 2006.

46. GRINBERGA L. Environmental factors influencing the species diversity of macrophytes in middle-sized streams in Latvia. Hydrobiologia 656, 233, 2010.

47. CYR H., STORISTEANU D.M.L., RIDGWAY M.S. Sediment accumulation predicts the distribution of a unionid mussel (Elliptio complanata) in nearshore areas of a Canadian Shield lake. Freshw. Biol. 57, 2125, 2012.

48. MILNER V.S., GILVEAR D.J. Characterization of hydraulic habitat and retention across different channel types; introducing a new field-based technique. Hydrobiologia 694, 219, 2012.

49. LORENZ A.W., KORTE T., SUNDERMANN A., JANUSCHKE K., HAASE P. Macrophytes respond to reach-scale river restorations. J. Appl. Ecol. 49, 202, 2012.

50. CHAMBERS P.A., KAIFF J. Depth distribution and biomass of submersed aquatic macrophyte communities in relation to Secchi depth. Can. J. Fish. Aquat. Sci. 42, 701, 1985.

51. RIIS T., SUREN A. M., CLAUSEN B., SAND-JENSEN $\mathrm{K}$. Vegetation and flow regime in lowland streams. Freshw. Biol. 53, 1531, 2008.

52. HACHOŁ J., BONDAR-NOWAKOWSKA E. Vulnerability of the biological elements of river bed ecosystem on regulatory works. J. Ecol. Eng. 18 (2), 51, 2017.

53. CAFFREY J.M., MONAHAN C., TIERNEY D. Factors influencing the distribution of aquatic plant communities in Irish canals. Hydrobiologia 570, 133, 2006.

54. HEARNE J.W., ARMITAGE P.D. Imlications of the annual macrophyte growth cycle on habitat in rivers. Regul. River. 8, 313, 1993.

55. WIEGLEB G., UDO BRÖRING U., FILETTI M., BRUX H., HERR W. Long-term dynamics of macrophyte dominance and growth-form types in two north-west German lowland streams. Freshwater Biol. 59, 1012, 2014.

56. LACOUL P., FREEDMAN B. Environmental influences on aquatic plants in freshwater ecosystems. Environ. Rev. 14, 89, 2006.

57. ZHU G., LI W., ZHANG M., NI L., WANG S. Adaptation of submerged macrophytes to both water depth and flood intensity as revealed by their mechanical resistance. Hydrobiologia 696, 77, 2012. 
58. SILVA D.S., CUNHA-SANTINO M.B., MARQUES E.E., BIANCHINI Jr. I. The decomposition of aquatic macrophytes: bioassays versus in situ experiments. Hydrobiologia 665, 219, 2011.

59. DEMARS B.O.L, POTTS J.M., TREMOLIÈRES M., THIÉBAUT G., GOUGELIN N., NORDMANN V. River macrophyte indices: not the Holy Grail! Freshwater Biol. 57, 1745, 2012.

60. GEBLER D., SZOSZKIEWICZ K., PIETRUCZUK K. Modeling of the river ecological status with macrophytes using artificial neural networks. Limnologica 65, 46, 2017.
61. ALLAN J.D., YUAN L.L., BLACK P., STOCKTON T., DAVIES P.E., MAGIEROWSKI R.H., READ S.M. Investigating the relationships between environmental stressors and stream condition using Bayesian belief networks. Freshw. Biol. 57, 58, 2012.

62. MARTINS S.V., MILNE J., THOMAZ S.M., MCWATERS S., MORMUL R.P., KENNEDY M., MURPHY K. Human and natural drivers of changing macrophyte communiy dynamics over 12 -years in a Neotropical riverine floodplain system. Aquat. Conserv. 23, 678, 2013. 